\title{
Some studies on the reaction between fly ash and lime
}

\author{
A BASUMAJUMDAR ${ }^{\dagger}$, A K DAS ${ }^{\dagger}, \mathrm{N}$ BANDYOPADHYAY and S MAITRA* \\ College of Ceramic Technology, WB University of Technology, Kolkata 700 010, India \\ 'Department of Chemical Technology, University of Calcutta, Kolkata 700 009, India
}

MS received 19 April 2004; revised 30 August 2004

\begin{abstract}
The reaction between fly ash (FA) and lime is extensively exploited for the manufacture of building bricks, blocks and aggregates. To get a better idea of this reaction, FA from different sources were mixed in different ratios with lime and compacted. The compacts were treated both by ordinary water and hydrothermal curing to promote lime bearing hydrate bond formation e.g. $\mathrm{CaO}-\mathrm{SiO}_{2}-\mathrm{H}_{2} \mathrm{O}(\mathrm{C}-\mathrm{S}-\mathrm{H}), \mathrm{CaO}_{-} \mathrm{Al}_{2} \mathrm{O}_{3}-$ $\mathrm{H}_{2} \mathrm{O}(\mathrm{C}-\mathrm{A}-\mathrm{H})$ etc. The decrease in free lime content in these compacts was measured as a function of curing time and curing process. This drop in this content was correlated to the chemical composition of the fly ashes. The mathematical relationships between free lime remaining in the compacts after its maximum decrease in concentration and lime binding modulus (a ratio between the amount of added lime and the total amount of lime binding constituents present in FA) for both types of curing were developed. Further, the rate of decrease in free $\mathrm{CaO}$ content under both types of curing conditions was compared from kinetic study. From this study the orders of the reactions and rate constants were found out.
\end{abstract}

Keywords. Fly ash; lime; compacts; curing; kinetics.

\section{Introduction}

In the presence of moisture, fly ash reacts with lime at ordinary temperature and forms a compound possessing cementitious properties. The reaction between lime and fly ash produces calcium silicate hydrates, which are responsible for development of strength in fly ash-lime in the form of bricks and blocks. These bricks/blocks are suitable for use in masonry just like common burnt clay bricks at lower cost with added advantages.

Barbier (1986) studied on the possible uses of coal fly ash in the brick industry with respect to the availability and characteristics of the fly ash. Song et al (1996) studied the manufacture and properties of coal fly ash-clay bodies. Tsunematsu et al (1987) studied on the hydrothermal reactivity of fly ash with lime and gypsum with respect to the mineral composition. Kumar (2002) made a perspective study on fly ash-lime-gypsum bricks and hollow blocks for low cost housing development. Ma and Brown (1997) also studied the hydrothermal reaction of fly ash with $\mathrm{Ca}(\mathrm{OH})_{2}$ and $\mathrm{CaSO}_{4} \cdot 2 \mathrm{H}_{2} \mathrm{O}$. Muntcan et al (1987) studied on the autoclaved limestone materials with addition of fly ash. The physico-mechanical properties of the resulting siliceous limestone with $10-30 \%$ fly ash were found to be superior compared to the limestone obtained from lime and sand only. Wang et al (1996) studied on the reaction mechanism of fly ash-lime-water system. A model of the reaction was established.

\footnotetext{
*Author for correspondence (maitra_s@vsnl.net)
}

In the present investigation the reaction between fly ash and lime in compacted form was studied by measuring the free $\mathrm{CaO}$ remaining in the mix after different periods of curing. The mix compositions were varied and different curing conditions were employed. The relationships between free $\mathrm{CaO}$ remained in the mixes after optimum curing periods and chemical composition of fly ashes were developed and the kinetic parameters of these reactions were also studied.

\section{Experimental}

In the present investigation twelve fly ash samples from different power plants of West Bengal (India) were collected. The ash samples were collected from the same number of ash collection hopper for all these units following procedures as laid in IS: 1528-1974, Part-VII. Particle size distributions of the ash samples were measured by sieve analyses following specifications as laid in IS: 1528-1974, Part-XIV. For the measurement of bulk density of the ash samples a fixed volume of the sample was taken in a measuring cylinder, which was tapped for sufficient number of times for thorough packing and its weight was measured. Blain's air permeability apparatus was used for measuring the surface area of the ash sample. Specific gravity of the ash samples was measured by pycnometer following specifications as laid in IS: 15281974, Part-IX. Chemical analyses of the ash samples were carried out following conventional technique of sodium carbonate fusion. Pulverized lime with high percentage of $\mathrm{CaO}(>80 \mathrm{wt} \%)$ and considerable surface area 
$\left(10,800 \mathrm{~cm}^{2} / \mathrm{g}\right)$ was used in the present investigation. The test compacts were prepared by mixing fly ash and lime in different requisite proportions in a laboratory mixer. The mixing time was $6 \mathrm{~h}$ for all the cases as it was found to be optimum for homogeneous mixing. The optimality was tested analysing different random proportion of the mix for $\mathrm{SiO}_{2}$ and lime content. The homogeneous mix thus obtained was compacted with $5 \%$ moisture using a laboratory hydraulic press at different levels of compaction pressure (from $200 \mathrm{~kg} / \mathrm{cm}^{2}$ to $325 \mathrm{~kg} / \mathrm{cm}^{2}$ ). The test compacts were cured under two different conditions. In water curing the test specimens were immersed in water at ambient temperature. For steam curing the samples were kept in a low-pressure autoclave at an average steam pressure and temperature of $2.5 \mathrm{~kg} / \mathrm{cm}^{2}$ and $120^{\circ} \mathrm{C}$, respectively. The free lime content in the test specimens was measured chemically using the procedure described by Hanna et al (1938, 1939). Free lime was determined utilizing the solubility of lime in a solvent containing 1 part by volume of pure glycerol to 5 volumes of absolute alcohol. The glycerol used was anhydrous containing $99.5 \%$ glycerol with a specific gravity of 1.251 at $25^{\circ} \mathrm{C}$. The alcohol used was $99 \%$ ethyl alcohol. The indicator used was $0.18 \mathrm{~g}$ phenolphthalein in $2160 \mathrm{ml}$ of the mixed solvent. The solution used for titrating the lime was prepared by dissolving $16 \mathrm{~g}$ dry crystalline ammonium acetate in 1 litre of alcohol. It was standardized as follows: About $0 \cdot 1 \mathrm{~g}$ of freshly ignited $\mathrm{CaO}$ was placed in a $200 \mathrm{ml}$ Erlenmeyer flask and $60 \mathrm{ml}$ of glycerol-ethyl alcohol solvent was added to it and the $\mathrm{CaO}$ was dispersed by shaking. A reflux condenser was fitted and the mixture was boiled for 5-20 min and the mix was titrated again. This process was continued until the free $\mathrm{CaO}$ content did not increase by more than $0.05 \%$ after $2 \mathrm{~h}$ of boiling.

The free lime estimation was carried out by weighing $1 \mathrm{~g}$ of finely ground sample into a flask, adding $60 \mathrm{ml}$ of the solvent and proceeding as in the standardization of the ammonium acetate solution. The free lime content of cement was calculated as follows

$$
\% \mathrm{CaO}=\frac{100 E V}{W},
$$

where, $E$ is the equivalent of standard ammonium acetate solution in $\mathrm{g} \mathrm{CaO}$ per $\mathrm{ml}, \mathrm{V}$ the $\mathrm{ml}$ of ammonium acetate solution required and $W$ the weight of the sample taken.

\section{Results}

Lime reacts with oxide components like silica, alumina and iron oxide of FA to develop different types of lime bearing phases like calcium silicate, calcium aluminate, calcium aluminosilicate etc and these phases are subsequently hydrated in the presence of water to form different hydrates. These hydrates are responsible for the development of strength in the fly ash-lime compacts (Watt and Throne 1996).
From the chemical analysis of FA samples it was observed that the total amount of silica, alumina and iron oxides varied from 70-90\% in the compositions (table 1). Glassy phase content of the samples also varied between 75 and $85 \%$. Therefore, four different FA samples were selected from the lot for carrying out experiment with total pozzolanic oxide contents of $70 \%, 80 \%, 85 \%$ and $90 \%$, respectively (table 2). Particle size distribution of these four samples is shown in figure 1. These were likely to represent the trend in compositional variation that would affect the degree of interaction with lime. These different fly ash samples were mixed with lime in different ratios: $90: 10,80: 20,70: 30$ and $60: 40$, respectively.

\subsection{Effect of compaction pressure}

Compaction pressure has a distinct effect on the reaction between lime and fly ash. To study this effect fly ash and lime mixes were compacted at different pressures and the compacts were subjected to hydrothermal curing for a period of $10 \mathrm{~h}$. It was observed that a sharp reduction in free $\mathrm{CaO}$ content took place at a compaction pressure of $200 \mathrm{~kg} / \mathrm{cm}^{2}$ and after $300 \mathrm{~kg} / \mathrm{cm}^{2}$ of compaction pressure, no significant change in free lime concentration was observed. Compaction pressure enhanced the inter-granular contacts, thus facilitating the progress of reaction by increasing the formation of more interfacial contact areas between the reactants. But a critical inter-particle gap or space is required for the formation of different interfaces and migration of the lime bearing hydrated phases formed from its origin to other places. Perhaps at higher pressures this gap is reduced which decreases the rate of reaction. Therefore, in the present investigation all the compacts were prepared with a compaction pressure of $200 \mathrm{~kg} / \mathrm{cm}^{2}$.

The depletion in free lime concentrations in the compacts was observed to occur at comparatively rapid rate initially after the onset of curing process. But after a definite curing period, lime reaction rate slowed down and no significant change in free lime concentration took place.

\subsection{Curing conditions and lime binding modulus of fly ashes}

Curing under ambient condition (figure 2) revealed that the maximum reduction in the concentration of free $\mathrm{CaO}$ takes place between 50 and 55 days and beyond this period the drop in free $\mathrm{CaO}$ content in the samples was not significant. In case of hydrothermal curing condition this period was observed to be $10 \mathrm{~h}$ (figure 3 ). It was also observed that within this period, the extent of reduction in free $\mathrm{CaO}$ content varied from $87-96 \%$ for different fly ash-lime compacts. In samples with higher proportion of fly ash, the extent of reduction in free $\mathrm{CaO}$ content was observed to be more. It indicates that the rate of pozzo- 
Table 1. Physico-chemical properties of the ash samples.

\begin{tabular}{|c|c|c|c|c|c|c|c|c|}
\hline & \multicolumn{8}{|c|}{ A. Chemical composition of the ash samples $(\mathrm{A}-\mathrm{H})$} \\
\hline & $\begin{array}{c}\mathrm{A} \\
\mathrm{Wt} \%\end{array}$ & $\begin{array}{c}\mathrm{B} \\
\mathrm{Wt} \%\end{array}$ & $\begin{array}{c}\mathrm{C} \\
\mathrm{Wt} \%\end{array}$ & $\begin{array}{c}\text { D } \\
\mathrm{Wt} \%\end{array}$ & $\begin{array}{c}\mathrm{E} \\
\mathrm{Wt} \%\end{array}$ & $\begin{array}{c}\mathrm{F} \\
\mathrm{Wt} \%\end{array}$ & $\begin{array}{c}\mathrm{G} \\
\mathrm{Wt} \%\end{array}$ & $\begin{array}{c}\mathrm{H} \\
\mathrm{Wt} \%\end{array}$ \\
\hline $\mathrm{SiO}_{2}$ & $53 \cdot 20$ & $62 \cdot 20$ & $54 \cdot 30$ & $61 \cdot 11$ & $57 \cdot 48$ & $60 \cdot 11$ & $60 \cdot 20$ & $64 \cdot 31$ \\
\hline $\mathrm{Al}_{2} \mathrm{O}_{3}$ & $24 \cdot 50$ & $22 \cdot 50$ & $23 \cdot 30$ & $23 \cdot 80$ & $32 \cdot 60$ & $26 \cdot 55$ & 23.90 & $25 \cdot 60$ \\
\hline $\mathrm{Fe}_{2} \mathrm{O}_{3}$ & $6 \cdot 20$ & $7 \cdot 60$ & $8 \cdot 30$ & $7 \cdot 20$ & $3 \cdot 48$ & $5 \cdot 84$ & $7 \cdot 80$ & 4.45 \\
\hline $\mathrm{CaO}$ & 1.70 & 1.56 & 1.42 & $1 \cdot 35$ & 1.98 & 4.83 & 2.06 & 1.03 \\
\hline $\mathrm{MgO}$ & $1 \cdot 30$ & 1.01 & 0.68 & $1 \cdot 35$ & 1.06 & $1 \cdot 25$ & 0.70 & 0.97 \\
\hline LOI & $8 \cdot 40$ & $2 \cdot 40$ & $5 \cdot 80$ & $1 \cdot 14$ & $1 \cdot 22$ & 0.63 & $0 \cdot 35$ & 0.58 \\
\hline $\mathrm{Na}_{2} \mathrm{O}$ & $0 \cdot 30$ & $0 \cdot 21$ & 1.43 & $0 \cdot 30$ & $0 \cdot 28$ & $0 \cdot 22$ & 0.51 & 0.60 \\
\hline $\mathrm{K}_{2} \mathrm{O}$ & $2 \cdot 15$ & 0.92 & $1 \cdot 38$ & $1 \cdot 10$ & 0.46 & 0.75 & 0.73 & 1.02 \\
\hline $\mathrm{SO}_{3}$ & $0 \cdot 20$ & $0 \cdot 11$ & $0 \cdot 23$ & $0 \cdot 25$ & $0 \cdot 19$ & 0.35 & 1.97 & $0 \cdot 16$ \\
\hline $\mathrm{TiO}_{2}$ & 1.03 & 1.40 & 1.45 & $2 \cdot 10$ & 0.94 & 0.78 & 0.42 & - \\
\hline $\mathrm{Cl}$ & $0 \cdot 01$ & - & $0 \cdot 02$ & - & $0 \cdot 01$ & - & - & - \\
\hline $\mathrm{P}_{2} \mathrm{O}_{5}$ & 0.86 & - & - & - & $0 \cdot 24$ & - & - & - \\
\hline \multicolumn{9}{|l|}{ B. Physical properties } \\
\hline Bulk density $\left(\mathrm{g} / \mathrm{cm}^{3}\right)$ & 0.97 & $0 \cdot 70$ & $0 \cdot 91$ & 0.79 & $0 \cdot 86$ & $0 \cdot 90$ & $0 \cdot 82$ & 0.72 \\
\hline Specific gravity & $2 \cdot 50$ & 1.98 & $2 \cdot 21$ & $2 \cdot 11$ & $2 \cdot 14$ & $2 \cdot 43$ & $2 \cdot 12$ & 1.98 \\
\hline Surface area (Blain's, $\mathrm{cm}^{2} / \mathrm{g}$ ) & 5515 & 3960 & 3775 & 3358 & 6280 & 3025 & 4120 & 5210 \\
\hline
\end{tabular}

A. Chemical composition of the ash samples (I-L)

\begin{tabular}{|c|c|c|c|c|}
\hline & \\
\hline & $\begin{array}{c}\mathrm{I} \\
\mathrm{Wt} \%\end{array}$ & $\begin{array}{c}\mathrm{J} \\
\mathrm{Wt} \%\end{array}$ & $\begin{array}{c}\mathrm{K} \\
\mathrm{Wt} \%\end{array}$ & $\begin{array}{c}\mathrm{L} \\
\mathrm{Wt} \%\end{array}$ \\
\hline $\mathrm{SiO}_{2}$ & $62 \cdot 72$ & $61 \cdot 57$ & $52 \cdot 00$ & $56 \cdot 37$ \\
\hline $\mathrm{Al}_{2} \mathrm{O}_{3}$ & $29 \cdot 93$ & $26 \cdot 33$ & $23 \cdot 00$ & $26 \cdot 80$ \\
\hline $\mathrm{Fe}_{2} \mathrm{O}_{3}$ & $2 \cdot 13$ & $6 \cdot 35$ & $2 \cdot 30$ & $6 \cdot 10$ \\
\hline $\mathrm{CaO}$ & $2 \cdot 33$ & 0.94 & $10 \cdot 50$ & $2 \cdot 65$ \\
\hline $\mathrm{MgO}$ & $0 \cdot 72$ & $0 \cdot 84$ & $3 \cdot 25$ & $1 \cdot 15$ \\
\hline LOI & $0 \cdot 52$ & $1 \cdot 40$ & $2 \cdot 50$ & $2 \cdot 14$ \\
\hline $\mathrm{Na}_{2} \mathrm{O}$ & $0 \cdot 19$ & $0 \cdot 15$ & $1 \cdot 33$ & $0 \cdot 36$ \\
\hline $\mathrm{K}_{2} \mathrm{O}$ & $0 \cdot 25$ & $0 \cdot 70$ & $1 \cdot 88$ & $1 \cdot 17$ \\
\hline $\mathrm{SO}_{3}$ & $0 \cdot 19$ & $0 \cdot 30$ & $0 \cdot 63$ & $0 \cdot 35$ \\
\hline $\mathrm{TiO}_{2}$ & $0 \cdot 75$ & $2 \cdot 09$ & 1.95 & $1 \cdot 10$ \\
\hline $\mathrm{Cl}$ & - & - & $0 \cdot 02$ & - \\
\hline $\mathrm{P}_{2} \mathrm{O}_{5}$ & - & $0 \cdot 13$ & - & $0 \cdot 31$ \\
\hline \multicolumn{5}{|l|}{ B. Physical properties } \\
\hline Bulk density $\left(\mathrm{g} / \mathrm{cm}^{3}\right)$ & $0 \cdot 77$ & $0 \cdot 82$ & $0 \cdot 84$ & 0.91 \\
\hline Specific gravity & $2 \cdot 10$ & $2 \cdot 12$ & $2 \cdot 12$ & $2 \cdot 41$ \\
\hline Surface area (Blain's, $\mathrm{cm}^{2} / \mathrm{g}$ ) & 4510 & 2990 & 5172 & 3635 \\
\hline
\end{tabular}

lanic reaction between fly ash and $\mathrm{CaO}$ is the maximum up to a critical curing period. The anomalies observed in the intermediate regions might be due to the difference in reactivity of the FA samples, which depends on the particle size, chemical constituents, phase compositions, and the nature of the glassy phases present. Therefore, it may be inferred that the rate of formation of lime bearing hydrated phases such as $\mathrm{C}-\mathrm{S}-\mathrm{H}, \mathrm{C}-\mathrm{A}-\mathrm{H}$ was maximum up to this period.

The reaction between fly ash and lime can be considered mostly as interface controlled. In presence of water vapour the lime is converted to calcium hydroxide and the formed calcium hydroxide reacts with components like silica, alumina, iron oxide and titania constituents of
Table 2. Pozzolanicity of the fly ash samples.

\begin{tabular}{lc}
\hline Fly ash & $\begin{array}{c}\text { Pozzolanicity [total per cent of } \\
\left(\mathrm{SiO}_{2}+\mathrm{Al}_{2} \mathrm{O}_{3}+\mathrm{Fe}_{2} \mathrm{O}_{3}\right) \text { constituents] }\end{array}$ \\
\hline $\mathrm{A}$ & $83 \cdot 90$ \\
$\mathrm{~B}$ & $92 \cdot 30$ \\
$\mathrm{C}$ & $85 \cdot 90(\mathrm{FA} 2)$ \\
D & $92 \cdot 11$ \\
E & $93 \cdot 56$ \\
F & $92 \cdot 50$ \\
$\mathrm{G}$ & $91.90(\mathrm{FA} 3)$ \\
$\mathrm{H}$ & $94 \cdot 36$ \\
$\mathrm{I}$ & $94 \cdot 78(\mathrm{FA} 4)$ \\
J & $94 \cdot 25$ \\
$\mathrm{~K}$ & $77 \cdot 30(\mathrm{FA} 1)$ \\
L & $89 \cdot 27$ \\
\hline
\end{tabular}


FA to form calcium silicate, calcium aluminate, calcium ferrate and calcium titanate. Formation of complex phases like calcium aluminosilicate, calcium iron aluminium silicate cannot be ruled out. These lime-bearing phases are ultimately converted into their hydrates in presence of water vapour.

As lime only reacts with the neutral and acidic components of FA for the development of lime bearing hydrated phases on curing, major constituents like silica, alumina and iron oxide may be considered responsible for binding of lime. The ratio of concentration of initial added lime and the sum total of silica, alumina and iron oxide, i.e. $\mathrm{CaO} /\left(\mathrm{SiO}_{2}+\mathrm{Al}_{2} \mathrm{O}_{3}+\mathrm{Fe}_{2} \mathrm{O}_{3}\right)$, was designated as the lime binding modulus of fly ash.

The concentration of free $\mathrm{CaO}$ remaining after $\sim 55$ days for ordinary curing and after $\sim 10 \mathrm{~h}$ for hydrothermal curing may be taken as more or less constant as the rate of decrease in free $\mathrm{CaO}$ beyond these periods was found to be practically insignificant. Therefore, a rela-

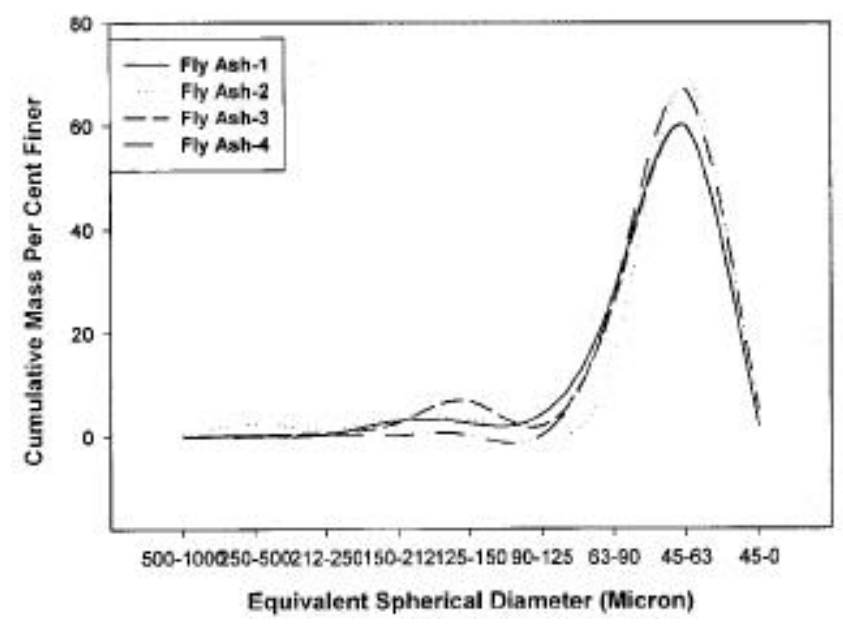

Figure 1. Particle size distribution of different fly ash samples.

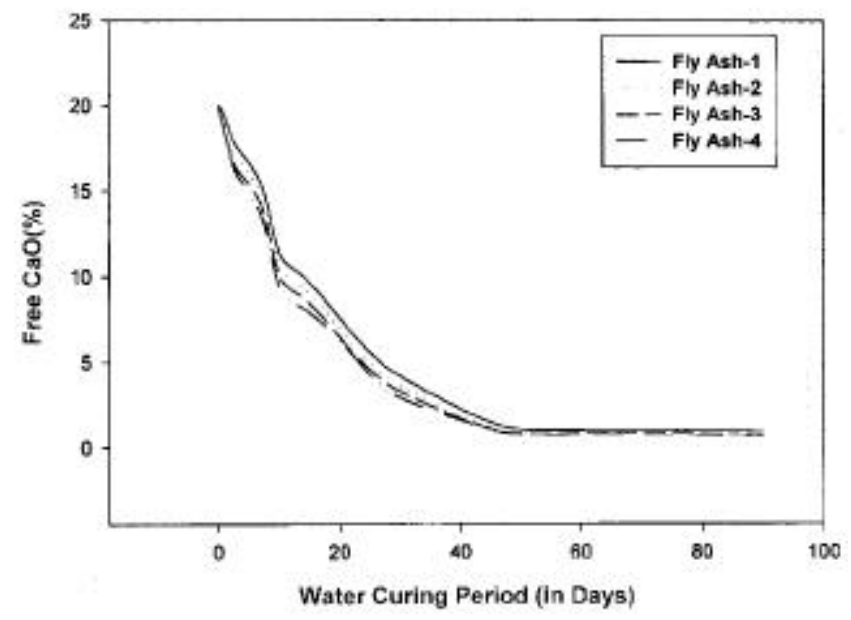

Figure 2. Variation in free $\mathrm{CaO}$ of fly ash-lime compacts (80:20) with water curing. tionship between lime binding modulus and free lime remaining at these mentioned periods was attempted to develop. Such relationship may be useful in formulating lime-fly ash mix for optimum performances. The relationship between lime binding modulus and free lime content for hydrothermal curing follows an exponential fit and the equation takes the following formula,

$$
y=a e^{(b x)}
$$

where, $y$ is the free $\mathrm{CaO}$ remaining in the compacts after $10 \mathrm{~h}$ and $x$ the lime binding modulus of fly ash. The values of the coefficient are $a=0.19$ and $b=7.36$, respectively. Standard error is 0.11 and correlation coefficient is 0.9937 .

The relationship between lime binding modulus and free lime content for water curing follows 4 th degree polynomial fit

$$
y=a+b x+c x^{2}
$$

$y=$ free $\mathrm{CaO}$ remaining in the compacts after 55 days and $x$ the lime binding modulus of fly ash. The values of the coefficient are $a=1 \cdot 28, b=-13 \cdot 90, c=54 \cdot 29$, standard error is 0.24 and correlation coefficient is 0.9848 , respectively.

The equations thus developed were tested on different fly ash-lime compacts with different lime binding modulus (appendix 1). The variations in all the cases were observed within $\pm 5-6 \%$. This might be related to the difference in mineralogical compositions, particularly the glassy phases in the fly ash samples.

From the relationship it is evident that the drop in free lime concentration under steam curing takes place at a faster rate compared to the natural curing process. This might be ascribed to the relatively more activation of the fly ash framework at elevated temperature and steam pressure.

To understand the nature of reaction of fly ash with lime, the order of the reaction was found out from the

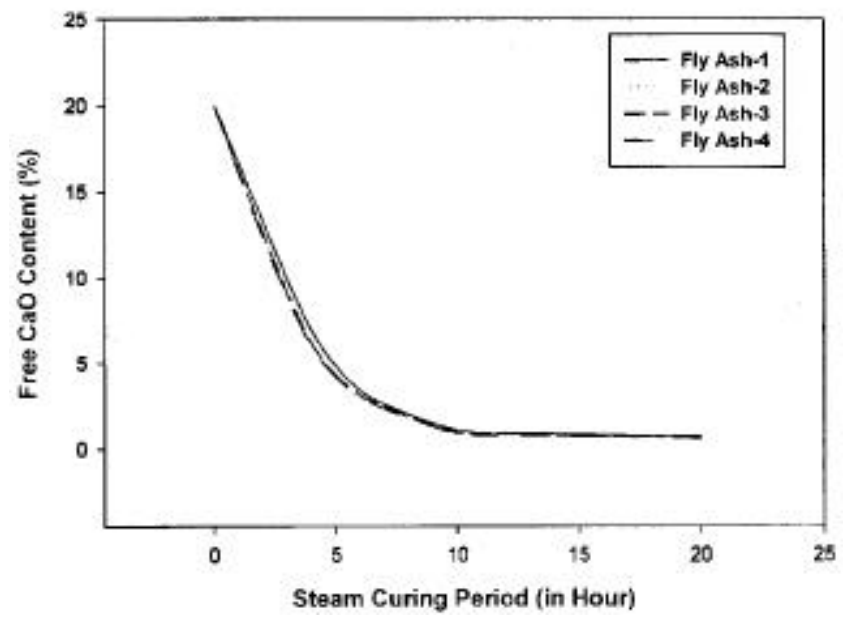

Figure 3. Variation in free $\mathrm{CaO}$ content of fly ash-lime compacts $(80: 20)$ with steam curing. 
previous experiment. For the sake of simplicity in the experimental procedures here only the fly ash with the maximum lime binding modulus was taken with four different compositions of fly ash and lime, ca., $90: 10$, $80: 20,70: 30$ and $60: 40$.

From the standard error and correlation coefficient of linearity of all the plots for different orders it might be concluded that for the water curing process the rate of reaction between fly ash and lime is most likely to follow first order kinetics with respect to the lime concentration while in steam curing the reaction between lime and fly ash in the compacted form is most likely to follow second order reaction kinetics with respect to the lime concentration. Probably steam pressure aids in the formation of more interfaces between fly ash and lime and the thermal energy associated with the steam helps in overcoming the energy barrier of the reaction. It was also observed that with the increase in lime concentration the values of the rate constants increased.

The rate of the reaction between fly ash and lime progressively decreased with curing time. This might be related to the formation of different lime bearing hydrated phases, such as calcium silicate hydrate, calcium aluminate hydrate etc on the surface of the ash particles. These hydrated phases cover the surface of the ash particles and reduce the contact of lime and particles further, thereby reducing the rate of reaction.

\section{Conclusions}

From the present investigation, it appeared that

(I) The optimum compaction pressure for making class $\mathrm{F}$ fly ash-lime compacts by water/steam curing process is $200-250 \mathrm{~kg} / \mathrm{cm}^{2}$.

(II) For water curing process the maximum reduction in free $\mathrm{CaO}$ content takes place after 50-55 days, whereas, for steam curing process the same takes place after $10 \mathrm{~h}$. (III) The relationship between lime binding modulus of fly ash $\left(\mathrm{CaO} / \mathrm{SiO}_{2}+\mathrm{Al}_{2} \mathrm{O}_{3}+\mathrm{Fe}_{2} \mathrm{O}_{3}\right)$ and free lime remaining after $10 \mathrm{~h}$ of steam curing is $y=a \cdot e^{b x}$, where $y$ is the free $\mathrm{CaO}$ content and $x$ the lime binding modulus of fly ash. The values of the coefficients are $a=0.19$ and $b=7 \cdot 36$, respectively. Standard error is 0.11 and correlation coefficient is 0.9937 .

(IV) The relationship between lime binding modulus of fly ash and free lime remaining after 55 days of water curing is $y=a+b x+c x^{2}$, where $y=$ free $\mathrm{CaO}$ remaining in the compacts after 55 days and $x$ the lime binding modulus of fly ash. The values of the coefficient are $a=$ $1 \cdot 28, b=-13.90, c=54 \cdot 29$, standard error is 0.24 and correlation coefficient is 0.9848 , respectively.

(V) The decrease in lime concentration with fly ash with curing time follows mostly first order kinetics and in case of steam curing it follows mostly second order kinetics with respect to the lime concentration in the mix.

\section{Appendix:}

Table A. Theoretical and experimental free lime content in samples after 10 hours of steam curing.

\begin{tabular}{lccc}
\hline $\begin{array}{l}\text { Lime binding } \\
\text { modulus }\end{array}$ & $\begin{array}{c}\text { Predicted free } \\
\text { lime after } 10 \mathrm{~h} \\
\text { of steam curing }\end{array}$ & $\begin{array}{c}\text { Determined free } \\
\text { lime after } 10 \mathrm{~h} \\
\text { of steam curing }\end{array}$ & $\begin{array}{c}\text { Variation } \\
(\%)\end{array}$ \\
\hline $0 \cdot 217$ & 0.938 & 0.987 & $5 \cdot 3(+)$ \\
$0 \cdot 32$ & $2 \cdot 00$ & 1.932 & $3 \cdot 4(-)$ \\
$0 \cdot 224$ & 0.987 & $1 \cdot 05$ & $6 \cdot 4(+)$ \\
$0 \cdot 357$ & $2 \cdot 64$ & $2 \cdot 79$ & $5 \cdot 9(+)$ \\
$0 \cdot 212$ & 0.903 & 0.927 & $2 \cdot 7(+)$ \\
$0 \cdot 424$ & $4 \cdot 3$ & 4.08 & $4.9(+)$ \\
$0 \cdot 112$ & $0 \cdot 43$ & 0.447 & $4 \cdot 1(+)$ \\
\hline
\end{tabular}

Table B. Theoretical and experimental free $\mathrm{CaO}$ content in samples after 55 days of water curing.

\begin{tabular}{lccc}
\hline $\begin{array}{l}\text { Lime binding } \\
\text { modulus }\end{array}$ & $\begin{array}{c}\text { Predicted free } \\
\text { lime after 55 days of } \\
\text { water curing }\end{array}$ & $\begin{array}{c}\text { Determined free } \\
\text { lime after 55 days of } \\
\text { water curing }\end{array}$ & $\begin{array}{c}\text { Variation } \\
(\%)\end{array}$ \\
\hline $0 \cdot 326$ & $2 \cdot 51$ & $2 \cdot 66$ & $6 \cdot 1(+)$ \\
$0 \cdot 448$ & $5 \cdot 95$ & $6 \cdot 27$ & $5 \cdot 5(+)$ \\
$0 \cdot 214$ & $0 \cdot 79$ & $0 \cdot 83$ & $4 \cdot 7(+)$ \\
$0 \cdot 238$ & $1 \cdot 05$ & $1 \cdot 02$ & $2 \cdot 8(-)$ \\
$0 \cdot 119$ & $0 \cdot 39$ & $0 \cdot 38$ & $1.9(-)$ \\
$0 \cdot 163$ & $0 \cdot 45$ & $0 \cdot 479$ & $6 \cdot 5(+)$ \\
$0 \cdot 265$ & $1 \cdot 416$ & 1.474 & $4 \cdot 1(+)$ \\
\hline
\end{tabular}


Table C. Standard error $(S)$, correlation coefficient values $(R)$ of linearity for plots of free lime concentration against curing period of different fly ash and lime ratios for different assumed orders and reaction rate constants $(k)$ from the order.

\begin{tabular}{lcccc}
\hline $\begin{array}{l}\text { A: Water curing } \\
\text { Fly ash: lime }\end{array}$ & Order & $S$ & $R$ & $k$ \\
\hline $9: 1$ & 1 & $0 \cdot 2530$ & 0.9607 & $3.22 \times 10^{-2}$ day $^{-1}$ \\
& 2 & $1 \cdot 6352$ & 0.9059 & \\
$4: 1$ & 1 & $0 \cdot 2530$ & 0.9611 & $2.6 \times 10^{-2}$ day $^{-1}$ \\
$7: 3$ & 2 & $0 \cdot 5332$ & $0 \cdot 8903$ & \\
& 1 & $0 \cdot 1957$ & 0.9833 & $2.19 \times 10^{-2}$ day $^{-1}$ \\
$3: 2$ & 2 & $0 \cdot 1225$ & 0.9616 & \\
& 1 & $0 \cdot 2148$ & 0.9778 & $2.5 \times 10^{-2}$ day $^{-1}$ \\
\hline
\end{tabular}

B: Steam curing

\begin{tabular}{lcccc} 
Fly ash: lime & Order & $S$ & $R$ & $k$ \\
\hline $9: 1$ & 1 & $0 \cdot 6279$ & 0.9511 & \\
& 2 & 1.9093 & 0.9700 & 1.0076 per cent $^{-1}$ hour $^{-1}$ \\
$4: 1$ & 3 & 0.9093 & 0.9134 & \\
& 1 & 0.9093 & 0.9134 & \\
$7: 3$ & 2 & $0 \cdot 3006$ & 0.9783 & $20.29 \times 10^{-2}$ per cent $^{-1}$ hour $^{-1}$ \\
& 3 & $0 \cdot 7031$ & 0.9418 & \\
$3: 2$ & 1 & $0 \cdot 5029$ & 0.9427 & \\
& 2 & $0 \cdot 1619$ & 0.9726 & $9.68 \times 10^{-2}$ per cent $^{-1}$ hour $^{-1}$ \\
& 3 & 0.3183 & 0.9613 & \\
& 1 & 0.4802 & 0.9471 & \\
& 2 & $0 \cdot 1153$ & 0.9768 & $7.52 \times 10^{-2}$ per cent $^{-1}$ hour $^{-1}$ \\
\hline
\end{tabular}

\section{References}

Barbier U 1986 Ind. Ital. Laterizi 4053

Hanna W C, Hicks T A and Saeger G A 1938 Bull. Am. Ceram. Soc. Test. Mater. 9447

Hanna W C, Hicks T A and Saeger G A 1939 Proc. Am. Soc. Test. Mater. 39314

Kumar S 2002 Construction and Building Materials 16519
Ma W and Brown P W 1997 Cem. Concr. Res. 271237

Muntcan M, Paul F and Haret B 1987 Mater. Constr. 17226

Song J T, Yun S D, Ryan D W and Han K S 1996 J. Korean Ceram. Soc. 33154

Tsunematsu S, Inow N and Hara N 1987 Gypsum and Lime 211 362

Wang X, Yang N and Zhang B 1996 J. Chin. Ceram. Soc. 24137 Watt J D and Thorne D J 1996 J. Appl. Chem. 15585 